\title{
Adiponectin exhibits proliferative and anti-apoptotic effects on ovarian cancer cells via PI3K/Akt and Raf/MEK/ERK pathways
}

\author{
Yueqin Feng ${ }^{1}$, Fengjin $\mathrm{Hao}^{2}$, Weina Wan ${ }^{1}$, Xuemei Wang ${ }^{2 \star}$ \\ ${ }^{1}$ Department of Ultrasound, First Affiliated Hospital of China Medical University, ${ }^{2}$ Department of Biochemistry and Molecular \\ Biology, China Medical University, Shenyang, Liaoning 110122, China
}

*For correspondence: Email: pw1292@163.com

Sent for review: 15 August 2018

Revised accepted: 26 October 2018

\begin{abstract}
Purpose: To elucidate the effects and the underlying mechanism of adiponectin on human ovarian cancer cells.

Methods: The level of adiponectin, adiponectin receptor-1, caspase-3 and bcl-2 in the serum and ascites of the patients were measured with enzyme-linked immunosorbent assay (ELISA), QPCR and Western blotting. The human ovarian cancer cell lines (Caov3 and SKOV3) were enumerated using 3(4,5-dimethylthiazol-2-yl)-2,5-tetrazolium bromide (MTT) assay. Western blotting was also used to determine the levels of $p$-Akt, $p$-ERK and cyclin $B$.

Results: Serum and ascite levels of adiponectin were significantly higher in ovarian cancer patients than in healthy patients $(p<0.05)$. Expression of adiponectin in the serum and ascites of patients in FIGO stage IV was remarkably higher than in earlier stages $(p<0.05)$. The proliferative effect of adiponectin on ovarian cells was dose-dependent. Adiponectin treatment significantly increased the expression of cyclin B in Caov3 and SKOV3, and reduced the levels of caspase-3 and bcl-2. Inhibitors of PI3K and MEK pathways significantly reduced the proliferation of attenuated Caov3 and SKOV3 by up-regulating cyclin $B$ upon adiponectin treatment $(p<0.05)$, and thus alleviated the inhibitory effect of adiponectin on the expressions of caspase-3 and bcl-2.

Conclusion: The findings demonstrate that adiponectin promotes proliferation of the cells via the PISK/Akt and Raf/MEK/ERK pathways, and also provide new insights into ovarian cancer treatmment.
\end{abstract}

Keywords: Adiponectin, Ovarian cancer, Proliferation, Apoptosis, PI3K/Akt pathway

\begin{abstract}
This is an Open Access article that uses a funding model which does not charge readers or their institutions for access and distributed under the terms of the Creative Commons Attribution License (http://creativecommons.org/licenses/by/4.0) and the Budapest Open Access Initiative (http://www.budapestopenaccessinitiative.org/read), which permit unrestricted use, distribution, and reproduction in any medium, provided the original work is properly credited.
\end{abstract}

Tropical Journal of Pharmaceutical Research is indexed by Science Citation Index (SciSearch), Scopus, International Pharmaceutical Abstract, Chemical Abstracts, Embase, Index Copernicus, EBSCO, African Index Medicus, JournalSeek, Journal Citation Reports/Science Edition, Directory of Open Access Journals (DOAJ), African Journal Online, Bioline International, Open-J-Gate and Pharmacy Abstracts

\section{INTRODUCTION}

Adiponectin, one of the cytokines secreted by adipose tissue[1,2], is a lipid-like and collagenlike protein encoded by apM1 gene [3]. The role of adiponectin in the occurrence and development of tumors is multiple and complex
$[4,5]$. For example, it inhibits the proliferation and migration of tumor cells while promoting their apoptosis via activation of the CAMP/PKA and AMPK pathways $[6,7]$. It also down-regulates the expression of vascular endothelial growth factor while suppressing the blood vessel formation $[8,9]$. 
Recently, increasing literatures have indicated that adiponectin may act as a tumor suppressor gene. Adiponectin suppresses the proliferation and migration of hepatocellular carcinoma cells [10], gastric cancer cells [11], breast cancer cells [13], prostate cancer cells [14] and endometrial cancer cells [15]. Adiponectin can activate different pathways by binding to its receptors; it regulates the activity of some growth factors and regulates the expression of oncogenes or tumor suppressor genes. Adiponectin stimulates the expression of nicotinamide adenine dinucleotidedependent histone deacetylase (Sirt1) via the promotion of the phosphorylation of AMPactivated protein kinase (AMPK), and inhibition of apoptosis in pancreatic cancer cells [17]. Adiponectin also promotes the migration and invasion of breast cancer cells via activating MAPK and PI3K pathways $[7,18]$, and promote the phosphorylation of signaling molecules such as STAT3, ERK1/2 and Akt in 786-O renal carcinoma cells.

Ovarian cancer is one of the most common gynecological malignancies since patients do not present obvious early symptoms and its diagnosis is usually poor. More than $70 \%$ of ovarian cancer patients are identified and confirmed at the terminal stage of the disease [19]. In a previous study, the expression ratio of adiponectin receptor $1 / 2$ in follicular cells of polycystic ovary syndrome patients was significantly higher compared with that in normal ovaries [20], but there are few studies on the role of adiponectin in ovarian cancer's development and progression. This study aims to investigate the effects and underlying mechanism of adiponectin on ovarian cancer cells.

\section{EXPERIMENTAL}

\section{Materials and reagents}

Adiponectin ELISA kit and recombinant protein were produced by $R \& D$, USA; rabbit anti-human adiponectin receptor 1 and bcl-2 antibodies were purchased from Abcam, USA; HRP labeled goat anti-mouse IgG and goat anti-rabbit IgG antibodies were obtained from ZSGB-BIO, China. Polymerase chain reaction (PCR) primers and MTT assay kit were purchased from Sangon Biotech, China. Rabbit anti-human Akt, p-AKt, ERK, p-ERK primary antibodies, and rabbit antihuman caspase- 3 were products of Cell Signaling Technology, USA. Mouse anti-human GAPDH antibody was obtained from Biotime, China, while rabbit anti-human cylcin antibody was produced by Santa Cruze, USA. Trizol reagent was obtained from Sigma Aldrich Co., Germany.

\section{Patients and clinical data}

Sixty three patients in total were included for this one year study. All the patients were divided into two groups: an observation group consists of 46 patients with ovarian cancer, and a control consists of 17 healthy patients. Patients in the observation group were aged between 40 and 59 years (mean age $=53.00 \pm 9.50$ years), while those in control were aged between 30 and 55 years (mean age $=43 \pm 12.50$ years). Patients in the observation group were diagnosed pathologically and met the following conditions: (1) confirmed FIGO stage; (2) absence of hypertension; and (3) absence of diabetes or other chronic diseases. The FIGO stages were I, II, III, and IV. Patients in the control group were subjected to physical examinations. Inclusion criteria were: (1) healthy women with no cancer; and (2) absence of gynecological diseases, hypertension, diabetes or other chronic diseases. This research was approved by Ethical Committee of Department of Biochemistry and Molecular Biology, China Medical University, Shenyang, Liaoning, China (approval no. 20150457), and followed the guidelines of Declaration of Helsinki promulgated in 1964 as amended in 1996 [21]. The patients and their family members signed written informed consent.

\section{Enzyme-linked immunosorbent assay (ELISA)}

Serum and ascites samples obtained from the patients were incubated overnight at $4{ }^{\circ} \mathrm{C}$ after the addition of enzyme-labeled primary antibody. The blocking condition was placing in room temperature for one hour. The mixture was further added with enzyme-labeled secondary antibody and kept at room temperature for one hour. Positive and negative controls were routinely employed.

\section{Cell culture}

Human ovarian cancer cell lines (Caov3 and SKOV3) were cultured with complete culture medium (FCS-RPMI 1640 medium), spiked with $10 \%$ fetal bovine serum and kept at $37^{\circ} \mathrm{C}$ in a humidified incubator in an atmosphere of $5 \%$ $\mathrm{CO}_{2}$. The entire operation was carried out in 10,000 -grade purification room in sterile conditions.

\section{MTT assay}

The cells at the concentration of $1 \times 10^{4}$ cells/well were inoculated into a 96-well plate in DMEM, and were incubated for $24 \mathrm{~h}$. Different concentrations of adiponectin $(0-200 \mathrm{ng} / \mathrm{mL})$ was spiked to the cells and the mixtures were 
further incubated for 24, 48, and $72 \mathrm{~h}$, respectively. After $72 \mathrm{~h}, 20 \mu \mathrm{L}$ of MTT solution (5 $\mathrm{mg} / \mathrm{mL}$ ) was supplemented to each well, and then incubated for another $4 \mathrm{~h}$. The medium was finally replaced with dimethyl sulfoxide (DMSO) solution and agitated (50 oscillations/min, 10 min). A microplate reader were used to determine the absorbances of the mixtures at $570 \mathrm{~nm}$. MTT assays of cells in each group were conducted in quintuplicate.

\section{Real-time quantitative PCR}

Trizol reagent was used to extract the total RNA from the cells. The RNA was then reversetranscribed to cDNA and subjected to real-time quantitative PCR (qPCR). The reactions were performed in a final $25-\mu \mathrm{L}$ reaction mixture volume. Reaction conditions were listed as follow: initial denaturation at $95{ }^{\circ} \mathrm{C}$ for $5 \mathrm{~min}$, followed by 40 cycles of $94{ }^{\circ} \mathrm{C}$ for $20 \mathrm{sec}, 61{ }^{\circ} \mathrm{C}$ for $20 \mathrm{sec}, 72{ }^{\circ} \mathrm{C}$ for $20 \mathrm{sec}$, and a final elongation at $72{ }^{\circ} \mathrm{C}$ for $5 \mathrm{~min}$. The following protocol of melting curve was used: 10 seconds at $56{ }^{\circ} \mathrm{C}$, and then 10 seconds at a $0.5{ }^{\circ} \mathrm{C}$ increment to a final temperature of $95^{\circ} \mathrm{C}$. The resultant $\mathrm{PCR}$ products were confirmed by subjecting them to gene sequencing. The examination of glyceraldehyde 3-phosphate dehydrogenase (GAPDH) was used as the internal control. The primer sequences were listed in Table 1.

Table 1: Primer sequences used

\begin{tabular}{ll}
\hline Primer & Sequence \\
\hline GAPDH & 5'-AAGGTGAAGGTCGGAGTCAAC-3' \\
& 5'-GGGGTCATTGATGGCAACAATA-3' \\
AdipoR1 & 5'-TGTTCCTCTTAATCCTGCCCA-3' \\
& 5'-CCAACCTGCACAAGTTCCCTT-3' \\
Cyclin B & 5'-GTTAGGGTGTCTTCTCGAATCGG- \\
& 3', \\
& 5'- \\
& TTTCTGCGTTAATTTTCGTGTTCCT-3' \\
\hline
\end{tabular}

\section{Western blotting}

We used the phosphate-buffered saline (PBS) to wash the cells treated with varied concentrations of adiponectin. After washing, the clean cells were lysed with ice-cold radioimmunoprecipitation assay buffer (RIPA). The BCA protein assay kit was used to determine the protein content. Sodium dodecyl sulfatepolyacrylamide gel electrophoresis (SDS-PAGE) was used to isolate the protein. The protein bands were transferred to PVDF membranes and incubated with primary antibodies (Akt, p-Akt, ERK, p-ERK, cyclin B and caspase-3). The membranes were then washed and subsequently incubated with horseradish peroxidaseconjugated secondary antibodies. We attenuated the primary and secondary antibodies $w$ at a ratio of 1 to 500 overnight at $4{ }^{\circ} \mathrm{C}$. The densities of the bands were estimated using Chemi-doc XRS imaging system.

\section{Statistical analysis}

All statistical analyses were performed with SPSS (13.0). Significant differences between the observation group and the control group were estimated using $t$-test. The data are presented as mean \pm standard devistion (SD). Statistically significant were accepted when $p<0.05$.

\section{RESULTS}

\section{Expression of adiponectin}

The levels of serum and ascites adiponectin expression were significantly higher in the patients belonging to the observation group than the control group $(p<0.05)$. The expression of adiponectin in the serum of patients in FIGO stage IV was significantly higher than that in stage I $(p<0.05)$, but no significant difference was observed in the corresponding expressions between the other stages ( $p>0.05$ : Figure $1 \mathrm{~A})$. The expressions of adiponectin in ascites of patients in stages III and IV were significantly higher than the corresponding expressions in the other stages ( $p<0.05$; Figure $1 \mathrm{~B})$.

\section{Expressions of adiponectin receptor-1 in} human ovarian cancer cell lines

The expression of adiponectin receptor-1 was significantly higher in SKOV3 than in Caov3 $(p<$ 0.05; Figure $2 \mathrm{~A}$ and $\mathrm{B}$ ).

\section{Effect of exogenous adiponectin on proliferation of Caov3 and SKOV3}

The proliferation of Caov3 and SKOV3 cells was dose-dependent and significantly higher than the corresponding proliferation in the control group $(p$ $<0.05$ Figures $3 \mathrm{~A}$ and $\mathrm{B}$ ).

\section{Expression of cyclin B in Caov3 and SKOV3 $48 \mathrm{~h}$ after treatment with adiponectin}

After $48 \mathrm{~h}$ adiponectin treatment, the expressions of cyclin $B$ in Caov3 and SKOV3 were significantly increased $(p<0.01$; Figure $4 \mathrm{~A}$ and B). 


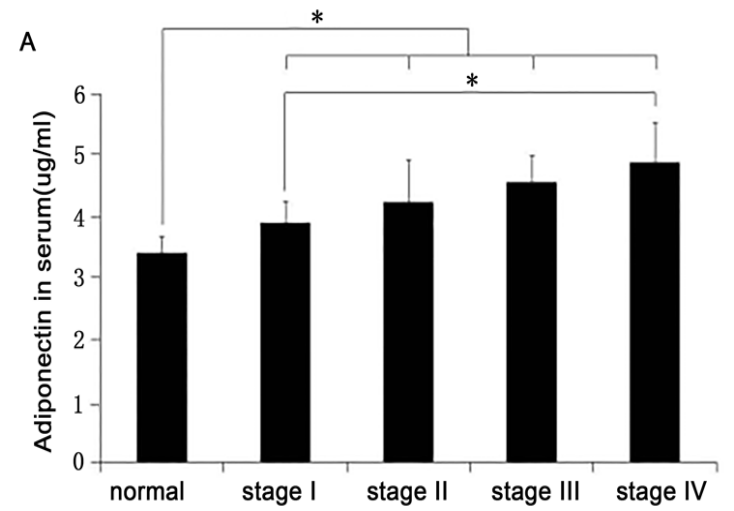

B $\quad$ a serum

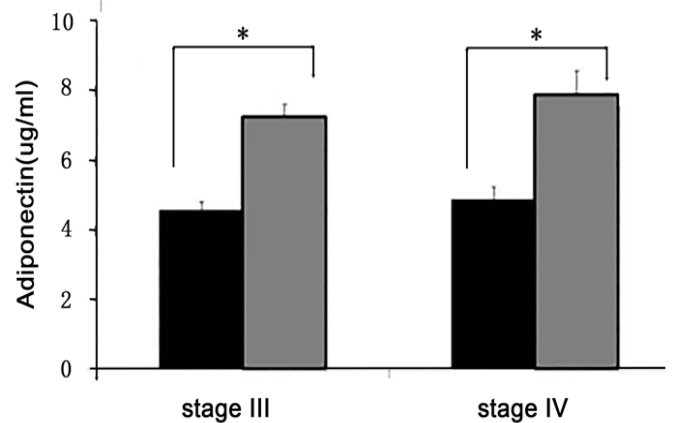

Figure 1: Expression of adiponectin in the two groups and FIGO stages. A: Expression of adiponectin in serum of patients in the observation and control groups; B: Expressions of adiponectin in ascites of patients in FIGO stages III and IV
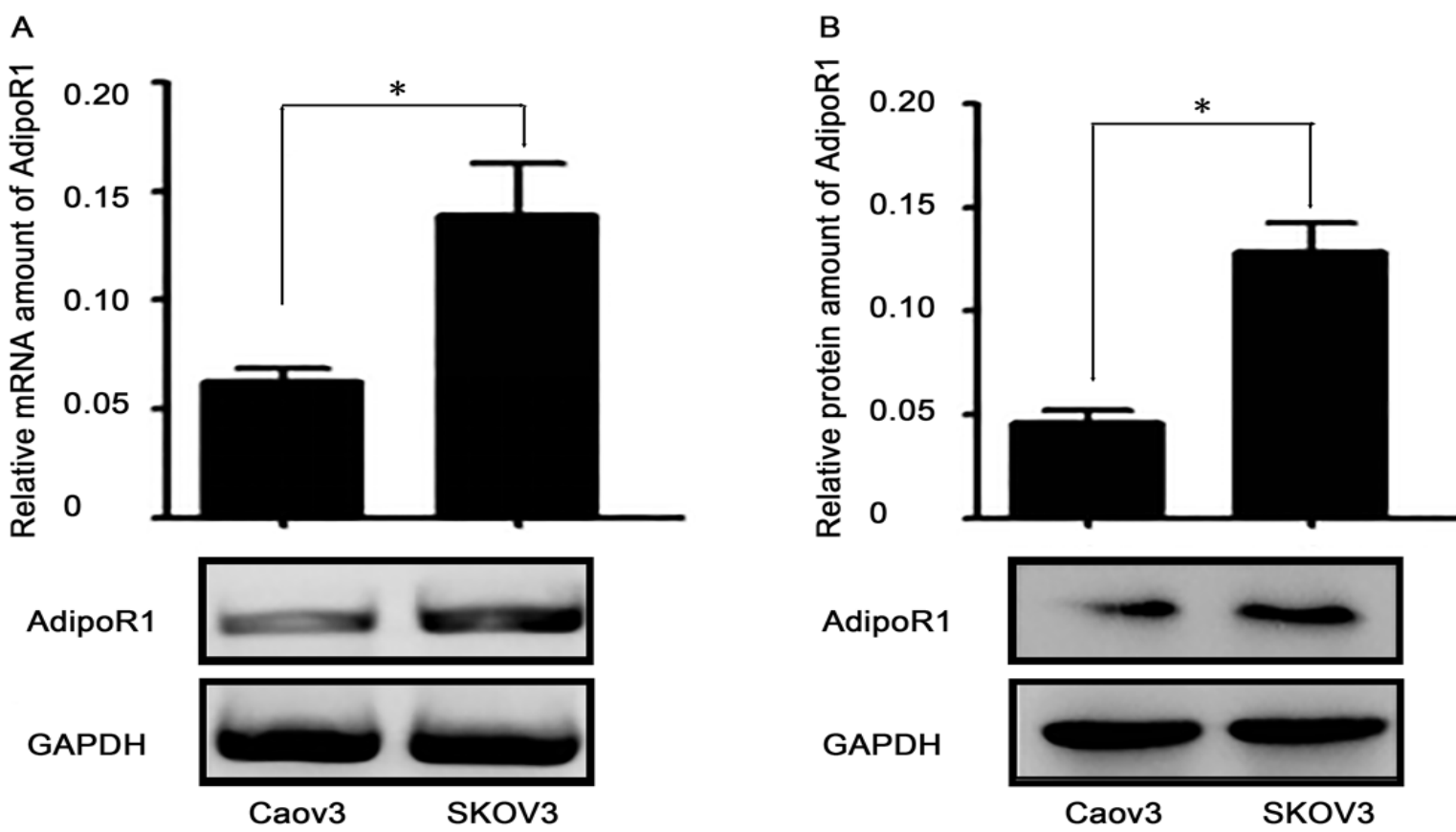

Figure 2: Expression of adiponectin receptor-1 in ovarian cancer cells. A: Expression of adiponectin receptors-1 in Caov3 and SKOV3, as measured using real-time qPCR; B: Expression of adiponectin receptor-1 in Caov3 and SKOV3, as measured using Western blotting
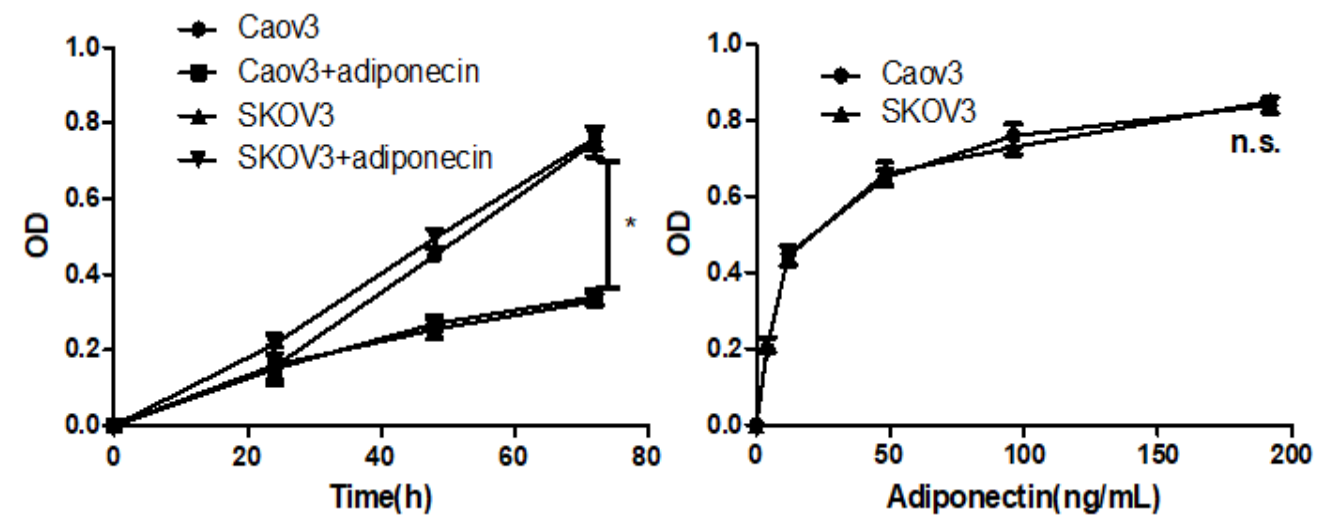

Figure 3: Effect of exogenous adiponectin on proliferation of ovarian cancer cells. A: After stimulation of adiponectin for different periods; B: $48 \mathrm{~h}$ after stimulation with varied concentrations of adiponectin 

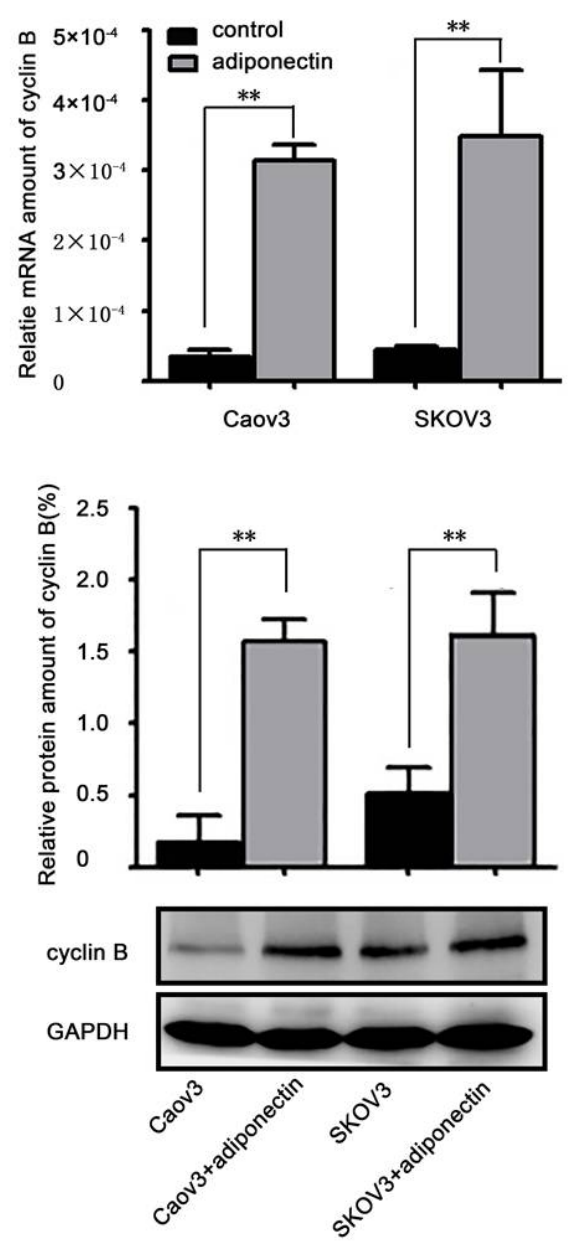

Figure 4: Expression of cyclin B in Caov3 and SKOV3 $48 \mathrm{~h}$ after treatment with adiponectin. Top: Relative mRNA expression of cyclin B before and after treatment with adiponectin; bottom: Relative protein expression of cyclin B before and after adiponectin treatment

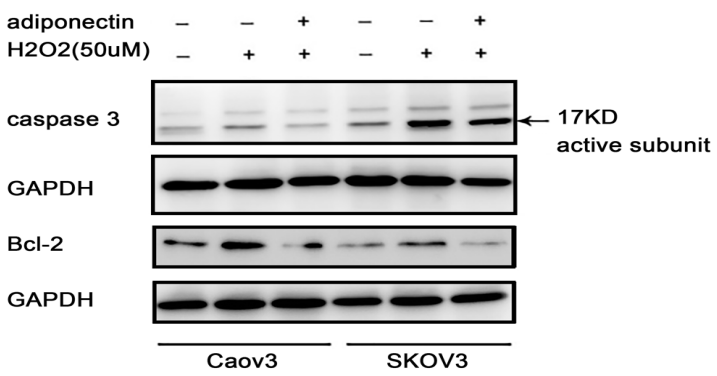

Figure 5: Expressions of apoptosis-related proteins after treatment with adiponectin

\section{Expression of apoptosis-related proteins after treatment with adiponectin}

The expressions of caspase- 3 and bcl-2 in Caov3 and SKOV3 were determined before and after treatment with adiponectin. The expressions of caspase-3 and bcl-2 were up-regulated in Caov3 and SKOV3 treated with $\mathrm{H}_{2} \mathrm{O}_{2}(50 \mu \mathrm{M})$. However, after treatment with both $\mathrm{H}_{2} \mathrm{O}_{2}(50 \mu \mathrm{M})$ and adiponectin, there were significant reductions in the expressions of caspase- 3 and bcl-2 (Figure 5).

\section{Effect of adiponectin on phosphorylation of Akt and ERK in ovarian cancer cells}

A significant increase was observed in the expression of $\mathrm{p}$-Akt after the adiponectin treatment. The expression peaked 10 and $30 \mathrm{~min}$ after treatments of Caov3 and SKOV3, respectively, with adiponectin. The expression of $\mathrm{p}$-ERK also increased after adiponectin treatment and peaked $60 \mathrm{~min}$ and $30 \mathrm{~min}$ after the treatment of Caov3 and SKOV3, respectively (Figure 6).

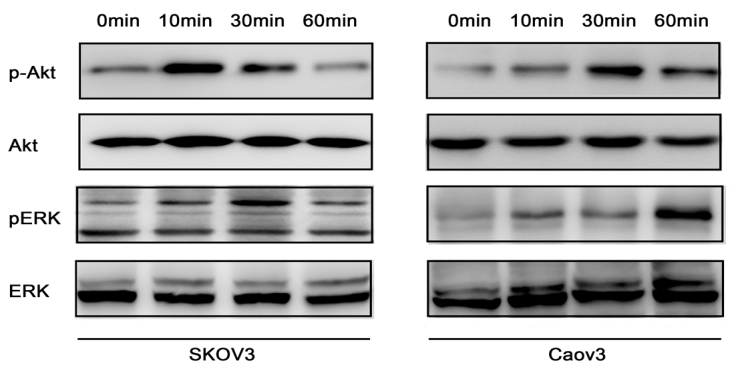

Figure 6: Effects of adiponectin on phosphorylation of Akt and ERK in SKOV3 and Caov3 treated with adiponectin

Effect of inhibitors of PI3K and MEK pathways on adiponectin-induced proliferation of human ovarian cancer cell lines

Inhibitors of PI3K (2-morpholin-4-yl-8-phenylchromen-4-one (LY294002)) and MEK (2-(2amino-3-methoxyphenyl)-4H-1-benzopyran-4one (PD98059)) pathways were used to determine the effect of adiponectin on the proliferation of Caov3 and SKOV3. inhibitors of $\mathrm{PI} 3 \mathrm{~K}$ and MEK pathways significantly reduced the proliferation of Caov3 and SKOV3 after 48 or $72 \mathrm{~h}$ of treatments $(p<0.05$, Figure 7$)$.
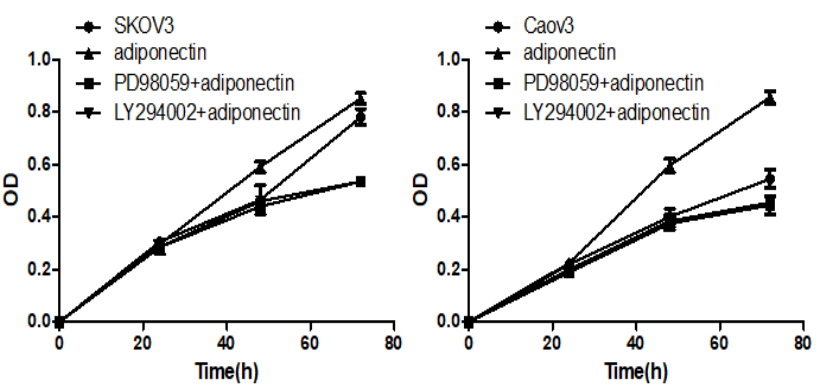

Figure 7: Effects of inhibitors of PI3K and MEK pathways on adiponectin-induced proliferation of human ovarian cancer cell lines. A: SKOV3; and B: Caov3

Trop J Pharm Res, November 2018; 17(11): 2145 


\section{Effect of inhibitors of PI3K and MEK pathways on adiponectin-induced inhibition of apoptosis}

The inhibitors of PI3K and MEK pathways significantly attenuated the up-regulation of cyclin $\mathrm{B}$ upon adiponectin treatment $(p<0.05)$. After treatment with inhibitors of $\mathrm{PI} 3 \mathrm{~K}$ and MEK pathways, the inhibitory effect of adiponectin on the expressions of caspase- 3 and bcl-2 was also attenuated (Figure 8).

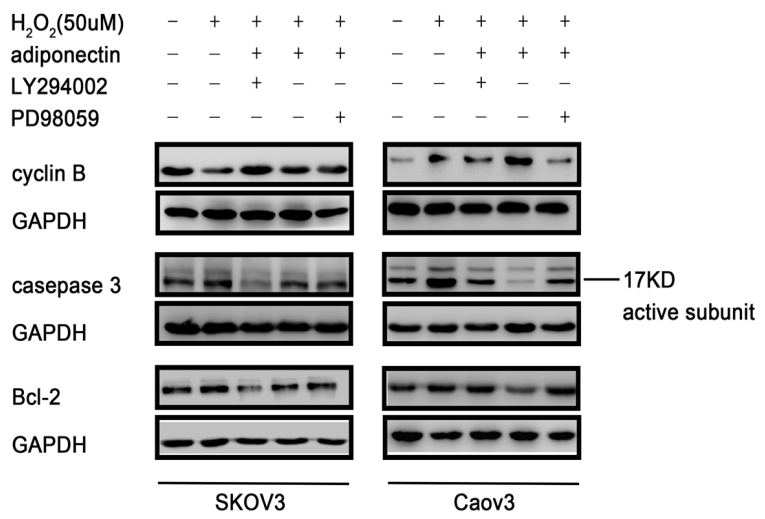

Figure 8: Expressions of cyclin $\mathrm{B}$, caspase-3 and bcl2 after treatment with $\mathrm{H}_{2} \mathrm{O}_{2}$, adiponectin, and inhibitors of PI3K and MEK pathways

\section{DISCUSSION}

Adiponectin is a fat factor that is relatively abundant in plasma [22] and mediates a variety of biological effects through its receptors expressed in cells of different tissues. Several studies have shown that there is a degree of correlation between its expression in the systemic circulation and the incidence of malignant tumors [23, 24].

In the present study, the expression of serum and ascites adiponectin was significantly higher in the observation group patients than the control group patients. The expression of adiponectin in the serum of patients in FIGO stage IV was significantly higher than that of stage I, but there were no significant differences of the corresponding expressions among other stages. The expressions of adiponectin in ascites of patients in stages III and IV were significantly higher than the corresponding expressions in the other stages. These results suggest that adiponectin may act as an oncogene in ovarian cancer. Our result is inconsistence with findings of Chen et al [25] and Arano et al [26], indicating that adiponectin may increase the risk of hepatocellular carcinoma.

It has also been reported that an increase in the serum level of adiponectin is associated with the late stage and poor differentiation of GC. Some authors have reported a negative correlation between the expression of adiponectin in the serum and the incidence of malignant tumors such as GC, breast cancer, endometrial cancer and prostate cancer $[27,28]$. High level of expression of adiponectin is an indication of better outcomes for patients with tumor metastasis [29]. Studies have shown that adiponectin can act as an oncogene or tumor suppressor gene in different tumors. However, some researchers have speculated that it plays contradictory roles in the development of tumors, regulation of metabolism, changes in cell microenvironment and direct influence on tumor cells [4]. A meta-analysis of patients with breast cancer revealed inconsistent results. So far, it is difficult to determine whether adiponectin acts as an oncogene or not [30].

In this study, the expression of adiponectin receptor-1 was significantly higher in SKOV3 than in Caov3. These results suggest that adiponectin may exert its biological effects by interacting with adipoR1 on the surface of ovarian cancer cells. In a previous study it was reported that $87.30 \%$ of patients with epithelial ovarian cancer expressed adipoR1, an indication that adipoR 1 is highly expressed in obesityrelated cancers [31]. Some authors have reported that the ratio of adipoR1 to R2 in follicular cells of patients with polycystic ovary was significantly higher than that in normal tissues [32]. In their studies, adiponectin inhibited the synthesis of androstenedione in follicular cells, luteinizing hormone (LH) receptors and the key enzymes of androgen synthesis. In this study, the effect of adiponectin on proliferations of Caov3 and SKOV3 cells were in a dosedependent manure and the level of proliferations in the observation group was significantly higher than that of control.

The expressions of cyclin B in Caov3 and SKOV3 were significantly increased after treatment with adiponectin. These results suggest that adiponectin up-regulated the expression of cyclin B. Apoptosis is the orderly programmed death of cells regulated by genes and enzymes so as to maintain the stability of the cell inner microenvironment. Cytochrome C released into the cytosol binds to apoptosisrelated factor 1 (Apaf-1) and promotes the formation of apoptotic bodies by recruiting caspase- 9 , which is followed by the activation of other caspases such as caspase-3, resulting in initiation of apoptosis.

It is believed that activated casepase- 3 initiates caspase-chain reaction in the apoptotic pathway. 
In the present study, the expressions of caspase3 and bcl-2 were up-regulated in Caov3 and SKOV3 treated with $\mathrm{H}_{2} \mathrm{O}_{2}$. However, after treatment with $\mathrm{H}_{2} \mathrm{O}_{2}$ and adiponectin, significant reductions in their expressions were detected. These results are consistent with a previous study which showed that increased serum level of adiponectin significantly inhibited apoptosis in pancreatic cancer cells [33]. Recent studies have also shown that AMPK may play an important role in the suppression of adiponectin-induced proliferation of tumor cells [34].

Some authors have suggested that adiponectin inhibits leptin-induced proliferation of hepatocellular carcinoma by blocking STAT-3, AKT, and $\mathrm{m}$-TOR pathways $[35,36]$. Proteins such as AdipoRs, APPL1, AMPK, JNK, AKT, MAPK-glucose transporter 4 (MAPK-GLUT4), GSK-3 $\beta$, IKB kinase, NF-KB and caspases are involved in tumorigenesis induced by adiponectin [37]. Adiponectin may promote the metastasis and invasion of breast cancer cells through MAPK and PI3K pathways, and induce the expression of VEGF in macrophages via the ERK pathway $[7,38]$.

The results of this study showed that adiponectin promote the phosphorylation of Akt and ERK. After treatment with inhibitors of PI3K and MEK pathways, the proliferations of Caov3 and SKOV3 at 48 or $72 \mathrm{~h}$ after the treatment were significantly reduced, an indication that adiponectin inhibit apoptosis in ovarian cancer cells and attenuate the down-regulation of casepase- 3 and bcl-2. These results suggest that adiponectin may promote the proliferation of ovarian cancer cells by inducing apoptosis via the PI3K/Akt and the Raf/MEK/ERK pathways. In recent years, the role of PI3K/Akt pathway in tumorigenesis has attracted huge attention, probably because it plays an important role in cell proliferation, apoptosis, migration, adhesion and degradation of extracellular matrix.

The molecule PI3K is a key in many physiological processes, having both serine/threonine protein kinase and phosphatidylinositol kinase activities. Activation of PI3K by cytokines promotes the binding of Akt to phosphatidylinositol to the serosal membrane through its $\mathrm{PH}$ domain, thereby activating it. The activated Akt is released into the cytosol where it activates downstream factors causing them to regulate cell proliferation, differentiation, growth and migration. The Ras/Raf/MEK/ERK pathway is considered to be a classical MAPK pathway. The MAPK pathway is at the center of several signaling pathways, and plays an important role in receiving signals from the membrane and transferring them to the cell nucleus. It also plays the leading role in many pathways related to cell proliferation.

MAPK family includes three major members of ERK, C-JUN amino-terminal kinase (JNK) and p38 mitogen-activated protein kinase (p38MAPK). ERK pathway can be activated by receptor tyrosine kinase, $G$ protein-coupled receptors and partial cytokine receptors. Studies have shown that MAPK pathway mediates signal transduction of several cytokines, thus acting on transcription factors to regulate cell proliferation, differentiation and apoptosis [39]. This is important in malignant transformation of cells.

\section{CONCLUSION}

The findings of this study demonstrate that adiponectin promotes proliferation of the cells via PIJK/Akt and Raf/MEK/ERK pathways, and thus provide new insights into ovarian cancer treatment.

\section{DECLARATIONS}

\section{Conflict of Interest}

No conflict of interest associated with this work.

\section{Contribution of Authors}

This work was done by the authors named in this article and the authors accept all liability resulting from claims which relate to this article and its contents. The study was conceived and designed by Xuemei Wang; Fengjin Hao and Weina Wan collected and analysed the data. Yueqin Feng wrote the text. All authors have read and approved the text prior to publication.

\section{REFERENCES}

1. Reeves GK, Pirie K, Beral V, Green J, Spencer E, Bull D. Cancer incidence and mortality in relation to body mass index in the Million Women Study: cohort study. BMJ 2007; 335(7630): 1134.

2. Davoodi SH, Malekshahabi T, Malekshahimoghadam A, Shahbazi R, Esmaeili S. Obesity as an important risk factor for certain types of cancer. Iran $J$ Cancer Prev 2013: 6(4): 186.

3. Modesitt SC, Van-Nagell JR. The impact of obesity on the incidence and treatment of gynecologic cancers: a review. Obstet Gynecol Surv 2005: 60(10): 683-692.

4. Hebbard L, Ranscht B. Multifaceted roles of adiponectin in cancer. Best Pract Res Clin Endocrinol Metab 2014; 28(1): 59-69.

Trop J Pharm Res, November 2018; 17(11): 2147 
5. Jia Z, Liu Y, Cui S. Adiponectin induces breast cancer cell migration and growth factor expression. Cell Biochem Biophys 2014; 70(2): 1239-1245.

6. Körner A, Pazaitoupanayiotou K, Kelesidis T, Kelesidis I, Williams CJ, Kaprara A, Bullen J, Neuwirth A, Tseleni S, Mitsiades N. Total and high molecular weight adiponectin in breast cancer: in vitro and in vivo Studies. $J$ Clin Endocrinol Metab 2007; 92(3): 1041.

7. Dieudonne $M N$, Bussiere M, Dos SE, Leneveu MC, Giudicelli $Y$, Pecquery R. Adiponectin mediates antiproliferative and apoptotic responses in human MCF7 breast cancer cells. Biochem Biophys Res Commun 2006; 345(1): 271-279.

8. Rose DP, Komninou D, Stephenson GD. Obesity, adipocytokines, and insulin resistance in breast cancer. Obes Rev 2004; 5(3): 153-165.

9. Bråkenhielm E, Veitonmäki $N$, Cao R, Kihara $S$, Matsuzawa $Y$, Zhivotovsky B, Funahashi T, Cao $Y$, Kishimoto T. Adiponectin-induced antiangiogenesis and antitumor activity involve caspase-mediated endothelial cell apoptosis. Proc Natl Acad Sci U S A 2004: 101(8): 2476.

10. Sharma $D$, Wang J, Fu PP, Sharma S, Nagalingam A, Mells J, Handy J, Page AJ, Cohen C, Anania FA. Adiponectin antagonizes the oncogenic actions of leptin in hepatocellular carcinogenesis. Hepatol 2010: 52(5): 1713-1722.

11. Tomoya $T$, Sachio $F$, Shinichi $H$, Shiroh $T$, Yasumichi $Y$, Jun $K$, Katsunobu $O$, Hidehiro $T$, Hideto $F$, Itasu $N$. Adiponectin receptor-1 expression is associated with good prognosis in gastric cancer. J Exp Clin Cancer Res 2011; 30(1): 107.

12. Williams CJ, Mitsiades N, Sozopoulos E, Hsi A, Wolk A, Nifli AP, Tselenibalafouta S, Mantzoros CS. Adiponectin receptor expression is elevated in colorectal carcinomas but not in gastrointestinal stromal tumors. Endocr Relat Cancer 2008; 15(1): 289.

13. Kim KY, Baek A, Hwang JE, Choi YA, Jeong J, Lee MS, Cho DH, Lim JS, Kim KI, Yang Y. Adiponectin-activated AMPK stimulates dephosphorylation of AKT through protein phosphatase 2A activation. Cancer Res 2009; 69(9): 4018

14. Housa D, Vernerová Z, Herácek J, Procházka B, Cechák $P$, Kuncová J, Haluzík M. Adiponectin as a potential marker of prostate cancer progression: studies in organconfined and locally advanced prostate cancer. Physiol Res 2008; 57(3): 451-458.

15. Zhang $L$, Wen $K$, Liu R. Effects of adiponectin on proliferation and apoptosis of endometrial cancer cells. Progress Obstet Gynecol 2010; 47(4): 458.

16. Wang Y, Lam KS, Xu JY, Lu G., XU LY, Cooper GJ, $X U$ A. Adiponectin inhibits cell proliferation by interacting with several growth factors in an oligomerizationdependent manner. J Biol Chem 2005; 280(18): 18341 18347.

17. Huang $B$, Cheng $X$, Wang $D$, Peng $M$, Xue $Z$, Da $Y$, Zhang $N$, Yao Z, Li M, Xu A. Adiponectin promotes pancreatic cancer progression by inhibiting apoptosis via the activation of AMPK/Sirt1/PGC-1a signaling. Oncotarget 2014; 5(13): 4732-4745.

18. Chou SH, Tselenibalafouta S, Moon HS, Chamberland JP, Liu X, Kavantzas N, Mantzoros CS. Adiponectin receptor expression in human malignant tissues. Horm Cancer 2010; 1(3): 136-145.

19. Westin SN, Herzog TJ, Coleman RL. Investigational agents in development for the treatment of ovarian cancer. Invest New Drugs. 2013; 31(1): 213-229.

20. Comim FV, Hardy K, Franks S. Adiponectin and its receptors in the ovary: further evidence for a link between obesity and hyperandrogenism in polycystic ovary syndrome. Plos One 2013; 8(11): 80416.

21. World Health Organization. Declaration of Helsinki. Br Med J 1996; 313(7070): 1448-1449.

22. Scherer PE, Williams S, Fogliano M, Baldini G, Lodish HF. A novel serum protein similar to C1q, produced exclusively in adipocytes. J Biol Chem 1995; 270(45): 26746.

23. He JY, Tu C, Li MJ, Wang SL, Guan XM, Lin JF, Li ZH. Nampt Visfatin PBEF A Functionally Multi-faceted Protein with a Pivotal Role in Malignant Tumors. Curr Pharm Des 2012; 18(37): 6123-6132.

24. Landskroner-Eiger S, Qian B, Muise ES, Nawrocki AR, Berger JP, Fine EJ, Koba W, Deng YF, Pollard JW, Scherer PE. Proangiogenic Contribution of Adiponectin toward Mammary Tumor Growth In vivo. Clin Cancer Res 2009; 15 (10): 3265-3276

25. Chen MJ, Yeh YT, Lee KT, Tsai CJ, Lee HH, Wang SN. The promoting effect of adiponectin in hepatocellular carcinoma. J Surg Oncol 2012; 106(2): 181-187.

26. Arano T, Nakagawa $H$, Tateishi R, Ikeda $H$, Uchino $K$, Enooku K, Goto E, Masuzaki R, Asaoka Y, Kondo Y. Serum level of adiponectin and the risk of liver cancer development in chronic hepatitis $C$ patients. Int $J$ Cancer 2011; 129(9): 2226.

27. Nishihara $T$, Baba $M$, Matsuda $M$, Inoue $M$, Nishizawa $Y$, Fukuhara A, Araki H, Kihara S, Funahashi T, Tamura S. Adiponectin deficiency enhances colorectal carcinogenesis and liver tumor formation induced by azoxymethane in mice. World $J$ Gastroenterol 2008; 14(42): 6473-6480.

28. Dalamaga M, Migdalis I, Fargnoli JL, Papadavid E, Bloom E. Mitsiades N, Karmaniolas K, Pelecanos N, Tseleni-Balafouta S, Dionyssiou-Asteriou A. Pancreatic cancer expresses adiponectin receptors and is associated with hypoleptinemia and hyperadiponectinemia: a case-control study. Cancer Causes Control 2009; 20(5): 625-633.

29. Duggan C, Irwin ML, Xiao L, Henderson KD, Smith AW, Baumgartner RN, Baumgartner KB, Bernstein $L$, Ballard-Barbash R, Mctiernan A. Associations of insulin resistance and adiponectin with mortality in women with breast cancer. J Clin Oncol 2011; 29(1): 32-39.

30. Liu LY, Wang M, Ma ZB, Yu LX, Zhang Q, Gao DZ, Wang $F, Y u$ ZG. The role of adiponectin in breast cancer: a meta-analysis. Plos One 2013; 8(8): 73183.

Trop J Pharm Res, November 2018; 17(11): 2148 
31. Wu $D$, Li $H Q$, Xiang GA, Zhang $L W$, Li LH, Cao YM, Zhang JQ. Adiponectin and Its Receptors in Chronic Hepatitis B Patients With Steatosis in China. Hepat Mon 2013; 13(4): 6065.

32. Cao ZZ, Li J, Luo LN, Li XS, Liu M, Gao M, Yin YH, Luan $\mathrm{XH}$. Molecular cloning and expression analysis of adiponectin and its receptors (AdipoR1 and AdipoR2) in the hypothalamus of the Huoyan goose during different stages of the egg-laying cycle. Reprod Biol Endocrinol 2015; 13: 87. https://doi.org/10.1186/s12958-015-00851

33. Goktas S, Yilmaz MI, Caglar K, Sonmez A, Kilic S, Bedir S. Prostate cancer and adiponectin. Urology 2005; 65(6): 1168-1172.

34. Kim AY, Lee YS, Kim KH, Lee JH, Lee HK, Jang SH, Kim $S E$, Lee $G Y$, Lee J W, Jung $S A$, Chung $H Y$, Jeong $S$, Kim JB. Adiponectin represses colon cancer cell proliferation via AdipoR1- and -R2-mediated AMPK activation. Mol Endocrinol 2010; 24(7): 1441-1452.
35. Halberg N, Schraw TD, Wang ZV, Kim JY, Yi J, Hamilton $M P$, Luby-Phelps K, Scherer PE. Systemic fate of the adipocyte-derived factor adiponectin. Diabetes 2009; 58(9): 1961.

36. Miyazaki T, Bub JD, Uzuki M, Iwamoto Y. Adiponectin activates C-Jun NH2-terminal kinase and inhibits signal transducer and activator of transcription 3. Biochem Biophys Res Commun 2005; 333(1): 79-87.

37. Chen $X$, Wang $Y$. Adiponectin and breast cancer. Med Oncol 2011; 28(4) 1288-1295.

38. Hu D, Fukuhara A, Miyata Y, Yokoyama C, Otsuki M, Kihara S, Shimomura I. Adiponectin regulates vascular endothelial growth factor- $C$ expression in macrophages via Syk-ERK pathway. Plos One 2013; 8(2): 56071.

39. Whitmarsh AJ. Regulation of gene transcription by mitogen-activated protein kinase signaling pathways. Biochim Biophys Acta - Mol Cell Res 2007; 1773(8): 1285-1298. 